\title{
HUKUM MENGHADIRKAN SAKSI PADA TRANSAKSI UTANG PIUTANG PERSPEKTIF MUHAMMAD ABDUH
}

\author{
Muhammad Alwin Abdillah \\ (Dosen Fakultas Syariah IAIN Langsa)
}

\begin{abstract}
Abstarct: Debt Receivable In Islam is a Jaiz thing or is allowed, but Islam regulates the systematic debt indebtedness. Fluctuations in economic conditions sometimes force someone to borrow money. The loan application is usually diverse, ranging from official financial institutions such as banking or any dimension online. However, there are also some circles who prefer to borrow on friends and relatives. Not without reason, the loan is certainly no frills interest and any collateral. As long as mutual trust, loans will certainly be given. Unfortunately, however, many are abusing the belief by not paying the debt on time. In fact, there are also deliberately pretending to forget.
\end{abstract}

Keyword: Debt receivable, debt receivable law.

Abstrak: Piutang Hutang Dalam Islam adalah hal Jaiz atau diizinkan, tetapi Islam mengatur hutang hutang sistematis. Fluktuasi kondisi ekonomi terkadang memaksa seseorang untuk meminjam uang. Aplikasi pinjaman biasanya beragam, mulai dari lembaga keuangan resmi seperti perbankan atau dimensi online apa pun. Namun, ada juga beberapa kalangan yang lebih suka meminjam pada teman dan kerabat. Bukan tanpa alasan, pinjaman ini tentu tanpa embel-embel bunga dan jaminan apa pun. Selama saling percaya, pinjaman pasti akan diberikan. Sayangnya, bagaimanapun, banyak yang menyalahgunakan kepercayaan dengan tidak membayar hutang tepat waktu. Bahkan, ada juga yang sengaja pura-pura lupa.

Kata kunci: Hutang piutang, hukum piutang utang.

\section{PENDAHULUAN}

Islam mengatur hubungan yang kuat antara akhlak, akidah, ibadah, dan muamalah. Aspek muamalah merupakan aturan main bagi manusia dalam menjalankan kehidupan sosial, sekaligus merupakan dasar untuk membangun sistem perekonomian yang sesuai dengan nilai-nilai Islam. Ajaran muamalah akan menahan manusia dari menghalalkan segala cara untuk mencari rezeki. Muamalah mengajarkan manusia memperoleh rezeki dengan cara yang halal dan baik. Permasalahan tentang hutang sangat banyak, bahkan hutang bisa memutus

\begin{abstract}
hubungan silaturahim bahkan persengketaan diantara manusia, Rasulullah Shallallaahu 'alaihi wa Sallam membaca doa: "(Artinya = Ya Allah aku berlindung kepada-Mu dari bahaya hutang bahaya musuh dan kemenangan para musuh)" begitu kawatirnya Rasulullah tentang hutang dari pada musuh dan kemenangan para musuh. Makalah ini akan membahas tentang hutang, yang bersumber dari hadits-hadits nabi Muhammad SAW. Dalam makalah ini kita akan mendapat jawaban dari pertanyaan itu semua, semoga makalah ini sesuai dengan yang kita harapkan dan
\end{abstract}


menambah pahala bagi penulis dan juga para membaca untuk mengamalkannya.

Hutang Piutang Dalam Islam merupakan hal yang sifatnya Jaiz atau diperbolehkan, namun Islam mengatur tata cara hutang piutang tersebut secara sistematis. Fluktuasi keadaan ekonomi terkadang memaksa seseorang untuk meminjam uang. Pengajuan pinjaman tersebut biasanya beragam, mulai dari lembaga keuangan resmi seperti perbankan atau pun yang berdimensi online. Namun, ada juga beberapa kalangan yang lebih memilih untuk meminjam pada sahabat dan saudara. Bukan tanpa alasan, pinjaman tersebut tentu tanpa embelembel bunga dan agunan apa pun. Asalkan saling percaya, pinjaman tentu akan diberikan. Namun sayangnya, banyak yang menyalah gunakan kepercayaan tersebut dengan tidak membayar hutang tepat pada waktunya. Bahkan, ada juga yang sengaja pura-pura lupa.

\section{MENGENAL MUHAMMAD ABDUH}

Muhammad Abduh adalah seorang sarjanah, pendidik, mufti, 'alim, teolog dan tokoh pembaharu Islam terkemuka dari Mesir. Muhammad Abduh memiliki nama lengkap Muhammad bin Abduh bin Hasan Khairullah (M. Quraish Shihab, 1994:11). Ia dilahirkan dari keluarga petani pada tahun $1849 \mathrm{M}$ atau $1266 \mathrm{H}$, di suatu desa di Mesir Hilir. Mengenai di desa mana ia dilahirkan masih belum diketahui secara pasti. Sedangkan tahun $1849 \mathrm{M}$ adalah tahun yang umum dipakai sebagai tahun kelahirannya. Namun, ada yang mengatakan bahwa ia lahir pada tahun sebelumnya yaitu 1848 M. Perbedaan pendapat tentang tempat, tanggal dan tahun lahirnya disebabkan karena pada saat itu terjadi kekacauan di akhir kepemimpinan Muhammad Ali (1805-1849 M). Kekerasan yang dipakai oleh penguasa-penguasa Muhammad Ali dalam mengumpulkan pajak dari penduduk-penduduk desa, menyebabkan para petani selalu berpindah tempat tinggal untuk menghindari beban-beban berat yang dilakukan penguasa-penguasa Muhammad Ali kepada mereka. Sehingga Ayah dari Muhammad Abduh sendiri selalu berpindah tempat tinggal dari desa ke desa, dan dalam kurun waktu satu tahun saja Ayah Muhammad Abduh sudah beberapa kali pindah tempat tinggal. Sehingga pada akhirnya Ayah Muhammad Abduh menetap di desa Mahallat Nashr dan membeli sebidang tanah di sana.

Ayah Muhammad Abduh bernama Abduh bin Hasan Khairullah, ia mempunyai silsilah keturunan dengan bangsa Turki yang telah lama tinggal di Mesir. Sedangkan Ibu dari Muhammad Abduh bernama Junainah. Menurut riwayat hidupnya Ibu Muhammad Abduh berasal dari bangsa Arab yang silsilah keturunannya sampai ke Umar bin Khattab yaitu Khalifah kedua (Khulafaur Rasyidin) (Muhammad Abduh, 1989: 59). Abduh Ibn Hasan Khairullah menikah dengan Ibu Junainah sewaktu merantau dari desa ke desa dan ketika ia menetap di Mahallat Nashr, Muhammad Abduh masih dalam ayunan dan gendongan Ibunya. Muhammad Abduh lahir dan beranjak dewasa dalam lingkungan pedesaan di bawah asuhan Ibu dan 
Ayahnya yang tidak memiliki hubungan dengan pendidikan sekolah, tetapi memiliki jiwa keagamaan yang teguh. Namun, di desanya Ayahnya sangat dikenal sebagai orang terhormat yang suka memberi pertolongan. Muhammad Abduh berkata : ....Saya tadinya beranggapan bahwa Ayahku adalah manusia termulia di kampung saya. Lebih jauh, beliau saya anggap manusia yang termulia di dunia ini, karena ketika itu saya mengira bahwa dunia ini tiada lain kecuali kampung Mahallat Nashr. Pada saat itu para pejabat yang berkunjung ke desa Mahallat Nashr lebih sering mendatangi dan menginap di rumah kami dari pada di rumah kepala desa, walaupun kepala desa lebih kaya dan mempunyai banyak rumah serta tanah. Hal ini menimbulkan kesan yang dalam atas diri saya bahwa kehormatan dan ketinggian derajat bukan ditentukan oleh harta atau banyaknya uang. Saya juga menyadari, sejak kecil betapa teguhnya Ayahku dalam pendirian dan tekad serta keras dalam perilaku terhadap musuhmusuhnya. Semua itulah yang kutiru dan kuambil, kecuali kekerasannya.

\section{PENDIDIKAN DAN PENGALAMAN MUHAMMAD ABDUH}

Dalam lingkungannya,

Muhammad Abduh memang berasal dari keluarga petani yang tinggal di pedesaan. Hampir semua saudaranya membantu Ayahnya mengelola usaha pertanian, kecuali Muhammad Abduh yang oleh Ayahnya ditugaskan untuk menuntut ilmu pengetahuan. Pilihan ini mungkin hanya suatu kebetulan atau mungkin juga karen ia sangat dicintai oleh Ayah dan Ibunya. Hal tersebut terbukti dengan sikap Ibunya yang tidak sabar ketika ditinggal oleh Muhammad Abduh ke desa lain untuk menuntut ilmu. Baru dua minggu sejak kepergiannya, Ibunya sudah datang menjenguk.

Hal ini sangat terlihat bahwa kedua orang tua Muhammad Abduh sangat perhatian terhadap pendidikannya. Sejak kecil Muhammad Abduh sudah disuruh belajar menulis dan membaca di kampungnya. Agar kemudian ia dapat membaca dan menghafal Alquran. Setelah mahir membaca dan menulis, Ayahnya menyerahkan Muhammad Abduh kepada seorang guru yang hafidz Alquran untuk dilatih menghafal Alquran. Dalam jangka waktu dua tahun dan pada saat ia berumur 12 tahun, Muhammad Abduh sudah hafal Alquran. ${ }^{141}$ Pada tahun $1862 \mathrm{M}$ dan pada usia 13 tahun, Muhammad Abduh dikirim oleh Ayahnya untuk melanjutkan pendidikannya disebuah sekolah agama di Thanta yaitu di Masjid Syaikh Ahmadi sekitar $80 \mathrm{~km}$ dari Kairo, Mesir. Masjid ini kedudukannya dianggap nomor dua setelah Universitas Al-Azhar, dari segi tempat belajar Alquran dan menghafanya. ${ }^{142}$ Setelah hampir dua tahun belajar bahasa Arab, nahwu, shorf, fiqh dan lain sebagainya. Namun, ia merasa tidak mengerti apaapa. Tentang pengalaman ini Muhammad Abduh mengatakan "Satu setengah tahun saya belajar di Masjid Syaikh Ahmadi dengan tak mengerti suatu apapun. Ini adalah karena

\footnotetext{
141 Yusran Asmuni, Pengantar Studi, (Raja Grafindo Persada, 1998), hal. 78.

${ }^{142}$ Harun Nasution, Pembaharuan Dalam Islam, (Bulan Bintang, 19750, hal. 59.
} 
metodenya yang salah, guruguru mulai mengajak kita dengan menghafal istilah-istilah tentang nahwu atau fiqh yang tak kita ketahui artinya. Guruguru tak merasa penting apakah kita mengerti atau tidak mengeti arti-arti istilah itu"143

Metode belajar pada waktu itu ialah metode menghafal luar kepala. Pengaruh metode ini masih terdapat dalam zaman kita sekarang terutama di sekolah-sekolah agama. ${ }^{144}$ Pengalaman pertamanya dengan membaca di luar kepala, menghafal nash (teks) dan ulasan serta hukum yang tidak memberinya sarana untuk memahami atas sistem pendidikan di Mesir. ${ }^{145}$ Karena tidak merasa puas dengan pembelajaran di sana, Muhammad Abduh akhirnya melarikan diri dan meninggalkan pelajarannya di Thanta. Ia pergi bersembunyi disalah satu rumah pamannya di desa Syibral Khit. Tetapi setelah tiga bulan bersembunyi, ia dipaksa kembali pergi belajar ke Thanta. Namun, ia tetap tidak mau karena ia yakin bahwa belajar di Thanta tidak akan membawa hasil baginya. ${ }^{146}$ Akhirnya Muhammad Abduh bertekad untuk tidak melanjutkan pendidikannya dan ingin kembali ke desanya saja. Ia berniat untuk menjadi petani seperti yang dilakukan saudara-saudara serta kaum kerabatnya.

Setelah ia kembali di

${ }^{143}$ Ibid., hal. 59. Dikutip dari T. Al-Tanahi. Ed., Muzakkirat Al-Imam Muhammad Abduh, Cairo, Dar AlHilal, hal. 29.

${ }^{144}$ Harun Nasution, Pembaharuan Dalam Islam, (Bulan Bintang, 1975), hal. 59.

145 Ilyas Hasan, Para Perintis Zaman Baru Islam, (Mizan Bandung, Cetakan Pertama 1993), hal. 37.

${ }^{146}$ Harun Nasution, Pembaharuan Dalam Islam, (Bulan Bintang, 1975), hal. 59. kampungnya, pada tahun $1865 \mathrm{M}$ Muhammad Abduh menikah pada usia yang sangat muda yaitu 16 tahun. Tapi nasib rupanya membawanya menjadi orang besar. Niatnya untuk menjadi petani itu tidak dapat diteruskannya. Baru saja empat puluh hari menikah, Muhammad Abduh dipaksa orang tuannya untuk kembali belajar ke Thanta. Ia pun meninggalkan kampungnya, tapi ia bukan pergi ke Thanta untuk belajar malahan untuk bersembunyi lagi di rumah salah satu pamannya. Pamannya ini adalah orang yang akan merubah jalan hidup Muhammad Abduh. Orang itu bernama Syaikh Darwisy Khad. Ia adalah paman dari Ayah Muhammad Abduh. Syaikh Darwisy Khadr sudah banyak memiliki pengalaman, di mana ia pernah pergi merantau keluar Mesir dan belajar agama Islam dan tasawwuf (tarekat Syadziliah) di Libia dan Tripoli. Setelah selesai pendidikannya Syaikh Darwisy Khadr kembali ke kampungnya. ${ }^{147}$

Syaikh Darwisy Khadr tahu akan keengganan Muhammad Abduh untuk belajar, maka ia selalu membujuk Muhammad Abduh untuk membaca buku bersama-sama. Sedangkan Muhammad Abduh pada waktu itu benci melihat buku, dan buka yang diberikan oleh Syaikh Darwisy Khadr kepada Muhammad Abduh untuk dibaca malah ia lempar jauh-jauh. Lalu buku itu dipungut oleh Syaikh Darwisy kembali dan diberikan kepada Muhammad Abduh. Akhirnya Muhammad Abduh mau juga untuk membaca buku itu meski hanya

147 Yusran Asmuni, Pengantar Studi, (Raja Grafindo Persada, 1998), hal. 79. 
beberapa baris. Setiap habis satu kalimat, Syaikh Darwisy memberikan penjelasan luas tentang arti dan maksud yang terkandung dalam kalimat itu. Setelah beberapa hari membaca buku bersama-sama dengan cara yang diberikan oleh Syaikh Darwisy itu, sikap Muhammad Abduh pun berubah. Ia mulai menyukai buku dan ilmu pengetahuan. ${ }^{148}$ Sehingga hal tersebut membuat Muahmmad Abduh mulai mengerti apa yang dibacanya dan ia juga ingin mengerti dan mengetahui lebih banyak tentang ilmu yang ia pelajari. Setelah beberapa lama ia bersembunyi di rumah pamannya Syaikh Darwisy Khadr dan belajar di sana. Ia pun pergi dan kembali ke masjid Syaikh Ahmadi di Thanta, dan kali ini minat dan pandangannya untuk belajar telah jauh berbeda dibandingkan sewaktu pertama kali ke sana. ${ }^{149}$ Satu hal yang perlu dicatat, bahwa pada periode ini Muhammad Abduh sangat dipengaruhi oleh cara dan faham sufi yang ditanamkan oleh Syaikh Darwisy Khadr.

Setelah selesai belajar di masjid Syaikh Ahmadi di Thanta, Muhammad Abduh kembali harus meninggalkan keluarga dan istrinya untuk belajar ke Al-Azhar, Kairo, Mesir pada tahun 1866 M. Namun, sistem pengajaran di Al-Azhar ketika itu tidak berkenan di hatinya, karena menurut Abduh "kepada para Mahasiswa hanya dilontarkan pendapat-pendapat para ulama terdahulu tanpa mengantarkan mereka kepada usaha penelitian,

148 Harun Nasution, Pembaharuan Dalam Islam, (Bulan Bintang, 1975), hal. 60.

${ }^{149}$ Shihab, Studi Kritis Tafsir al-Manar, (Pustaka Hidayah, Bandung, 1996), hal 13. perbandingan dan pertarjihan. ${ }^{150}$

Hampir tidak mengherankan kalau pembaharuan sistem belajar mengajar ini menjadi keinginan besar Muhammad Abduh selama hidupnya. Selama belajar di AlAzhar Muhammad Abduh sempat berkenalan dengan sekian banyak dosen yang dikaguminya, anatara lain:

1. Syaikh Hasan Al-Thawil yang mengajar kitab-kitab filsafat karangan Ibnu Sina, logika karangan Aristoteles dan lain sebagainya. Padahal kitab-kitab tersebut tidak diajarkan di Al-Azhar pada waktu itu.

2. Muhammad Al-Basyuni, seorang yang banyak mencurahkan perhatian dalam bidang sastra bahasa, bukan melalui pengajaran tata bahasa melainkan melalui kehalusan rasa dan kemampuan mempraktikannya. ${ }^{151}$

Setelah beberapa tahun belajar di Al-Azhar pada tahun $1871 \mathrm{M}$, Jamaluddin AlAfghani datang ke Mesir dalam perjalanan ke Istambul. Pada usia ke 23 tahun Muhammad Abduh untuk pertama kalinya berjumpa dengan Al-Afghani. ${ }^{152}$ Ketika tahu bahwa Al-Afghani datang ke Mesir, Muhammad Abduh dan teman-teman Mahasiswanya pergi berjumpa ke tempat penginapan Al-Afghani di dekat Al-Azhar. Dalam pertemuan itu AlAfghani memberikan pertanyaanpertanyaan kepada mereka mengenai arti beberapa ayat Alquran. Kemudian ia menjelaskan tafsirannya sendiri.

150 Ibid., hal. 13. Dikutip dari Sayyid Quthb, Kasha'ish Al-Tashawwur Al-Islamiy (tanpa tahun), (cetakan III, 1968), hal. 19.

${ }^{151}$ Shihab, Studi Kritis Tafsir al-Manar, (Pustaka Hidayah, Bandung, 1996), hal. 14

${ }^{152}$ H. Munawir Sjadzali, Islam dan Tata Negara Ajaran, Sejarah dan Pemikiran (Jakarta: Universitas Indonesia (UI Press), 1990), hal. 120 
Selain itu Al-Afghani juga mengadakan kajian ilmiah, belajar tasawuf, ilmu sosial, politik, filsafat dan lain-lain. Tidak hanyak Muhammad Abduh saja yang ikut bergabung dalam forum diskusi ini, namun sekelompok mahasiswa Al-Azhar juga ikut bergabung bersamanya termasuk pemimpin Mesir di kemudian hari yaitu Sa'd Zaghlul. Namun pengikut Al-Afghani ini bukanlah akademisi Universitas yang kering. Al-Afghani aktif memberikan dorongan kepada siswa-siswanya ini untuk menghadapai intervensi Barat di Negeri mereka dan pentingnya melihat umat Islam sebagai umat yang satu. Sehingga Muhammad Abduh membuang habis sisa-sisa tasawuf yang bersifat pantang dunia itu, lalu memasuki dunia aktivisme sosiopolitik. ${ }^{153}$ Al-Afghani juga mengalihkan kecenderungan Muhammad Abduh dari tasawuf dalam arti yang sempit yaitu dalam bentuk tata cara berpakaian dan zikir. Selain itu tasawuf dalam arti yang lain yaitu perjuangan untuk perbaikan keadaan masyarakat dan membimbing mereka untuk maju serta membela ajaranajaran Islam. Hal ini dilakukan melalui pemahaman ajaran-ajaran lawan (kelompok asing) dan mempelajari faktor-faktor yang menjadikan dunia Barat mencapai kemajuan, guna diterapkan dalam masyarakat Islam selama faktor-faktor tersebut sejalan dengan prinsip-prinsip Islam. ${ }^{154} \mathrm{Al}$ Afghani juga memperkenalkan Muhammad Abduh kepada banyak karya-karya penulis Barat yang sudah

153 Ilyas Hasan, Para Perintis Zaman Baru Islam, (Mizan Bandung, Cetakan Pertama 1993), hal. 78-79.

${ }^{154}$ Shihab, Studi Kritis Tafsir al-Manar, (Pustaka Hidayah, Bandung, 1996), hal. 14. dierjemahkan ke dalam bahasa Arab. Serta mendiskusikan masalah-masalah politik dan sosial yang tengah dihadapi baik oleh rakyat Mesir sendiri maupun umat Islam pada umumnya.

Perjumpaan Muhammad Abduh dengan Al-Afghani ini meninggalkan kesan yang baik dalam diri Muhammad Abduh. Selain itu Muhammad Abduh tidak pernah pensiun dari dunia aktivisme seperti ini, kendatipun pada akhirnya ia harus menjauhkan diri dari revolusionisme Al-Afghani, demi pendekatan yang lebih evolusioner dan damai. Pada masa itu Muhammad Abduh telah mulai menulis artikelartikel tentang pembaharuan di surat kabar Al-Ahram, Kairo, yang pada waktu itu baru saja didirikan. Melalui media ini gema tulisan tersebut sampai ketelinga para pengajar di Al-Azhar yang sebagian besar tidak menyetujuinya. Namun, berkat kemampuan ilmiahnya serta pembelaan dari Syaikh Muhammad AlMahdi Al-Abbasi yang ketika itu menduduki jabatan "Syaikh Al-Azhar", Muhammad Abduh dinyatakan lulus pada tahun $1877 \mathrm{M}$ dan mendapatkan gelar alim di Al-Azhar pada umur 28 tahun. 155

Setelah lulus dari Al-Azhar, ia juga mengajar dirumahnya, di sana ia mengajar kitab Tahdzib Al-Akhlaq karangan Ibnu Miskawaih, mengajarkan sejarah peradaban kerajaan-kerajaan Eropa karangan Guizot yang diterjemahkan oleh AlTahtawi ke dalam bahasan Arab di tahun $1877 \mathrm{M}$ dan mukaddimah Ibn Khaldun. Pada tahun $1878 \mathrm{M}$ atas

155 Sjadzali, Hukum Islam dan Tata Negara Sejaran dan Pemikiran, (UI Press), hal. 121. 
usaha Perdana Mentri Mesir Riadl Pasya, ia diangkat menjadi dosen pada Universitas "Darul Ulum", di samping itu ia juga menjadi dosen di AlAzhar, ${ }^{156}$ untuk pertama kalinya ia mengajar di Al-Azhar dengan mengajar manthiq (logika) dan ilmu Al-kalam (teologi). ${ }^{157}$ Serta mengajar ilmu-ilmu bahasa Arab di Madrasah Al-Idarah wal-Alsun (sekolah administrasi dan bahasa-bahasa).

\section{LATAR BELAKANG PEMIKIRAN MUHAMMAD ABDUH}

Muhammad Abduh adalah seorang pelopor reformasi dan pembaharu dalam pemikiran Islam di Mesir. Ide-idenya yang cemerlang, meninggalkan dampak yang besar dalam tubuh pemikiran umat Islam. Ia lah pendiri sekaligus peletak dasardasar sekolah pemikiran pada zaman modern dan juga menyebarkannya kepada masyarakat. Dalam melakukan perbaikan Muhammad Abduh memandang bahwa suatu perbaikan tidaklah selamanya datang melalui revolusi atau cara yang serupa. Seperti halnya perubahan sesuatu secara cepat dan drastis. Akan tetapi juga dilakukan melalui perbaikan metode pemikiran pada umat Islam. Melalui pendidikan, pembelajaran dan perbaikan Akhlaq. Juga dengan membentuk masyarakat yang berbudaya dan berfikir yang nantinya bisa melakukan pembaharuan dalam agamanya. Sehingga dengan begitu akan tercipta rasa aman dan keteguhan dalam menjalankan agama Islam. Muhammad

156 Shihab, Studi Kritis Tafsir al-Manar, (Pustaka Hidayah, Bandung, 1996), hal. 14.

157 Muhammad Abduh, Risalah Tauhid,Jakarta, (Bulan Bintang, 1963), hal. 70.
Abduh menilai bahwa cara ini akan membutuhkan waktu yang lebih panjang dan lebuh rumit. Akan tetapi memberikan dampak perbaikan yang lebih besar dibanding melalui politik dan perubahan secara besar-besaran dalam mewujudkan suatu kebangkitan dan kemajuan.

Pembaharuan pemikiran yang dilakukan Muhammad Abduh bukanlah hanya sebuah penolaka secara satu persatu atau secara global terhadap pemikiran-pemikiran yang telah ada (pemikiran yang terdahulu). Pembaharuannya juga bukan hanya sebuah pemeliharaan terhadap pemikiran-pemikiran yang telah ada tersebut. Akan tetapi pembaharuan yang dilakukannya merupakan usaha untuk memperbaiki, mengembangkan dan menjadikan intisari pemikiranpemikiran yang telah ada tersebut agar disesuai dengan tuntunan zaman. Namun, Muhammad Abduh tidak pernah berfikir apalagi berusaha untuk mengambil alih secara utuh segala yang datang dari dunia Barat. ${ }^{158}$

Muhammad Abduh menyadari kemunduran umat Islam bila dikontraskan dengan masyarakat Barat. Menurut analisisnya, kondisi lemah dan terbelakang ini disebabkan oleh faktor eksternal, seperti hegemoni (kekuasaan) Barat yang mengancam eksistensi umat Islam, dan oleh realitas internal, seperti situasi yang yang diciptakan oleh umat Islam sendiri. Karena umat Islam tidak mau membuka diri untuk menerima hal-hal baru yang berasal dari Barat dan terus terpaku pada pemikiran Islam yang

\footnotetext{
${ }^{158}$ Shihab, Studi Kritis Tafsir al-Manar, (Pustaka Hidayah, Bandung, 1996), hal. 14.
} 
terdahulu. Muhammad Abduh menyadari seriusnya tantangan Barat, ia mengatakan:

....Bangsa Barat telah memasuki fasa baru yang bercirikan peradaban yang berdasarkan ilmu pengetahuan, seni, industri, kekayaan dan keteraturan, serta organisasi politik baru yang berdasarkan pada penaklukan yang disangga oleh sarana baru, seperti melakukan perang dan oleh senjata yang mampu menyapu bersih banyak musuh. Namun itu tidak berarti bahwa umat Islam harus menyerah kepada kekuasaan Barat atau meniru gaya hidup Barat. 159

Muhammad Abduh menegaskan bahwa Barat harus dilawan karena prinsip mereka yang tinggi tidak sesuai dengan sikap mereka terhadap rakyat yang ditaklukkan. Orang Mesir menderita karena percaya begitu saja kepada orang asing tanpa membedakan mana yang menipu dan mana yang tulus, mana yang benar dan mana yang berdusta, mana yang setia dan mana yang berkhianat. 160

Muhammad Abduh adalah orang Mesir pertama yang menunjukkan keterbelakangan masyarakat Mesir dan fakta bahwa masyarakat Mesir telah kehilangan kapasitas untuk memperbarui dirinya. Problem sosial dan politik Mesir menurut Muhammad Abduh terjadi karena warisannya sendiri, yang telah membuat Mesir tak mampu menanggapi tantangan zaman. Selain faktor ekternal, ada juga faktor internal yaitu adanya perpecahan antara umat Islam. Dengan adanya

${ }^{159}$ Muhammad Abduh, Risalah Tauhid,,(Jakarta, Bulan Bintang, 1963), hal. 70.

${ }^{160}$ Muhammad Abduh, Risalah Tauhid,,(Jakarta, Bulan Bintang, 1963), hal. 72. perpecahan antar umat Islam ini, menjadikan umat Islam melemah karena umat Islam menjadi berkelompok-kelompok dan menjadi bangsa-bangsa kecil dengan beragam sekte. Selain itu tercabang duanya kekhalifahan di Mesir. Kemunduran umat Islam disebabkan oleh kebodohan dan kerana perpecahan sekterian, karena tertutupnya pintu ijtihad dan adanya kekeliruan kebijakan pemimpin Islam. Bagi Muhammad Abduh zaman Islam yang ideal itu adalah zaman Nabi Muhammad dan sahabatsahabatNya. Karena pada saat itu kecenderungan intelektual masih mewarnai umat Islam dan masih belum ada perpecahan mazhab atau pemikiran. ${ }^{161}$

\section{CORAK PEMIKIRAN MUHAMMAD} ABDUH

1. Modernisasi

Sebagaimana yang telah disinggung pada latar belakang pemikiran Muhammad Abduh, bahwa semenjak perjumpaannya dengan al-Afgani, Abduh berusaha mengadakan penyesuaian ajaran Islam dengan tuntutan zaman, seperti penyesuaian dengan perkembangan ilmu pengetahuan dan tekhnologi. Gagasan penyesuaian inilah kemudian disebut dengan moderniasasi. Sumber dari gagasan moderenisasi Abduh tersebut bersumber dari penentangannya terhadap taqlid. Menurut Muhammad Abduh, alQur'an memerintahkan kepada ummatnya untuk menggunakan akal sehat mereka, serta

161 Harun Nasution, Pembaharuan Dalam Islam, (Bulan Bintang, 1975), hal. 61-62. 
melarangnya mengikuti pendapatpendapat terdahulu tanpa mengikuti secara pasti hujah-hujah yang menguatkan pendapat tersebut, walaupun pendapat itu dikemukakan oleh orang yang seyogyanya paling dihormati dan dipercaya. Abduh menetapkan tiga hal yang menjadi kritrea perbuatan taqlid ini, ketiga kriteria tersebut adalah:

a. Sangat mengagung-agungkan para leluhur dan para guru mereka secara berlebihan.

b. Mengiktikadkan agungnya pemuka-pemuka agama yang silam, seolah-olah telah mencapai kesempurnaan.

c. Takut dibenci orang dan dikritik bila ia melepaskan fikirannya serta melatih dirinya untuk berpegang kepada apa yang dianggap benar secara mutlak.

Berdasarkan pada pandangan tersebut, Abduh memahami Alqur'an, terutama yang berkaitan denga kecaman terhadap sikap dan perbuatan taqlid tersebut, walaupun menyangkut sikap kaum musrikin. Selanjutnya ia mengecam kaum muslimin, khususnya yang berpengetahuan yang mengikuti pendapat ulama-ulama terdahulu tanpa memperhatikan hujahnya. ${ }^{162}$

Berkaitan dengan modernisasi ini, Rahman memberikan pernyataan bahwa seorang modernis biasanya memiliki beberapa ciri, diantaranya selalu berusaha menghadapi segala situasi dengan penuh keyakinan serta keberanian, dan gerakannya bersifat kerakyatan, serta senantiasa

162 Nur Cholis Madjid, Islam Kemodernan Dan Keindonesiaan, (Bandung: Mizan, 1989), hal. 172 melibatkan pemikiran pribadi. Kemudian kaum modernis yang telah menjadikan reformasi sebagai tolak ukurnya adalah mereka yang berusaha menciptakan ikatanikatan positif antara pemikiran Qur'ani dengan pemikiran modern. ${ }^{163}$ Perpaduan antara kedua pemikiran ini telah melahirkan beberapa lembaga sosial dan moral modern dengan berorientasi pada Alqur'an.

Muhammad Abduh menyikapi peradaban Barat modern dengan selektif dan kritis. Dia senantiasa menggunakan prinsip ijtihad sebagai metode utama untuk meretas kebekuan pemikiran kaum muslimin. Abduh tidak pernah berfikir, apalagi berusaha untuk mengambil alih secara utuh segala yang datang dari dunia Barat. Karena ia beranggapan apa bila itu dilakukan berarti mengubah taqlid yang lama dengan taqlid yang baru, juga karena hal tersebut tidak akan berguna, disebabkan adanya perbedaan-perbedaan pemikiran dan struktur sosial masyarakat masingmasing daerah. ${ }^{164}$ Islam menurut Abduh "harus mampu meluruskan kepincangan-kepincangan

perbedaan barat serta membersihkan dari segi-segi negatif yang menyertainya. Dengan demikian, perbedaan tersebut pada akhirnya, akan menjadi pendukung terkuat ajaran Islam, sesaat setelah ia mengenalnya dan dikenal oleh

\footnotetext{
163 Toto Suharto, Filsafat Pendidikan Islam, (Yogyakarta: Arruzz, 2006), hal. 258

164 M. Qurais Shihab, Studi Kritis Tafsir Al Manar, hal. 19
} 
pemeluk-pemeluk Islam. ${ }^{165}$

2. Reformis

Muhammad Abduh Adalah seorang pembaharu yang corak pembaharuannya bersifat reformistikrekonsturktif. Ini dikarenakan Muhammad

Abduh senantiasa melihat tradisi dengan perpektif membangun kembali. Agar tradisi suatu masyarakat dapat survive dan terus diterima, ia harus dibangun kembali. Pembangunan kembali ini tentunya dengan kerangka modern dan prasyarat rasional. Pemikiran pembaharuan yang bercorak reformistik dalam bentuknya yang pertama secara filosofis. 166

3. Konservatif

Gerakan pembaharuan yang diinagurasikan Muhammad

Abduh bersifat konservatif, hal ini terlihat dari sikap Muhammad Abduh yang tidak bermaksud mengubah potret diri Islam. Risalah Tauhid merupakan bukti dari pemikiran ini. Muhammad Abduh dalam karya ini berupaya menegaskan kembali potret diri Islam yang telah mencapai finalitas dan keunggulan. ${ }^{167}$

Demikianlah muncul ke permukaan ketiga tipologi pemikiran, yaitu modernis, reformis, konservatif, yang dilontarkan berkaitan dengan pembaharuan yang dilakukan Muhammad_Abduh. Ketiganya merupakan refleksi

165 M. Qurais Shihab, Studi Kritis Tafsir Al Manar, hal. 20

166 Toto Suharto, Filsafat Pendidikan Islam, (Yogyakarta: Arruzz, 2006), hal. 265.

167 Toto Suharto, Filsafat Pendidikan Islam, hal. 266 dalam membaca segala pemikiran Muhammad Abduh. Dalam pembacaan itu corak pertama lebih menekankan pada aspek slektifitas dan sikap kritis Muhammad Abduh dalam menyikapi dan memandang peradaban barat. Corak kedua lebih menekankan kepada upaya Muhammad Abduh_dalam membangun kembali tradisi Islam secara rekonstruktif. Sedangkan corak yang ketiga memfokuskan bacaannya kepada upaya Muhammad Abduh dalam membela Islam melalui finalitas dan keunggulan Islam.

\section{MANHAJ PEMIKIRAN MUHAMMAD ABDUH}

Islam adalah agama yang terdiri dari beberapa aspek yang saling erhubungan, satu dengan yang lainnya. Yaitu Aqidah (Teologi), Syariah (Hukum Islam), dan Akhlak (tasawuf). Namun dalam kesempatan ini, penulismemilih hanya membahas sedikit manhaj pemikiran Muhammad Abduh tentang Syariah dan Aqidah. Karena inilah yang mungkin paling mempengaruhi seseorang dalam bertindak. ${ }^{168}$

1. Hukum Islam

Dalam salah satu tulisannya, Abduh membagi syariat menjadi dua bagian, yaitu; hukum yang pasti (al Ahkam al Qath'iyah) dan hukum yang tak ditetapkan secara pasti dengan nash dan ijma. Hukum yang pertama, bagi setiap muslim wajib mengetahui dan mengamalkannya. Hukum yang seperti ini terdapat dalam alQur'an dan rinciannya telah

${ }^{168}$ Muhammad Abduh, Risalah Tauhid, hal. 25.

184 | Hukum Menghadirkan Saksi Pada Transaksi Utang Piutang Perspektif Muhammad Abduh 
dijelaskan Nabi melalui perbuatannya, serta disampaikan oleh kaum muslimin secara berantai dengan praktek. Hukum ini merupakan hukum dasar yang telah disepakati(mu jma' 'alaîhi) kepastiannya. Hal ini bukan merupakan lapangan ijtihad dan dalam hukum yang telah pasti serupa ini, seseorang boleh bertaklid. Yang kedua adalah hukum yang tidak ditetapkan dengan tegas oleh nash yang pasti dan juga tidak terdapat konsensus ulama didalamnya. Hukum inilah yang merupakan lapangan ijtihad, seperti masalah muamalah, maka kewajiban semua orang untuk mencari dan menguraikannya sampai jelas. ${ }^{169}$

Disinilah peranan para mujtahid, dan dari masalah ini pula lahir madzhab-madzhab fiqh yang merupakan cerminan dari keragaman pendapat dalam memahami nash-nash yang tidak pasti tersebut.

Abduh sangat menghargai para mujtahid dari madzhab apapun. Menurutnya, mereka adalah orang-orang yang telah mengorbankan kemampuannya yang maksimal untuk mendapatkan kebenaran dengan niat yang ikhlas serta ketaqwaan yang tinggi kepada Allah. Berbeda pendapat adalah hal yang biasa, dan tidak selamanya merupakan ancaman bagi kesatuan umat. Yang dapat menimbulkan bencana adalah jika pendapat yang berbeda-beda tersebut dijadikan sebagai tempat berhukum, dengan tunduk kepada pendapat tertentu saja, tanpa berani melakukan kritik atau mengajukan pendapat lain. Keseragaman berfikir dalam semua hal adalah kemustahilan. Menurutnya, setiap muslim harus memandang bahwa hasil ijtihad ulama masa lalu sebagai hasil pemikiran manusia biasa yang tidak selamanya benar. Sikap yang harus diambil umat Islam dalam perbedaan pendapat adalah kembali kepada sumber asli.

Untuk itu, Abduh menunjukkan dua cara yang harus dilakukan oleh umat Islam sesuai dengan adanya dua kelompok sosial yang biasanya terdapat dalam masyarakat Islam yaitu mereka yang memilki ilmu pengetahuan dan yang awam. Dia berpendapat bahwa kelompok pertama wajib melakukan ijtihad langsung kepada al Qur'an dan as Sunnah. Dalam hal ini ijtihad dituntut, karena kekosongan ijtihad dapat menyebabkan mereka akan mencari keputusan hukum di luar ketentuan syara'. Dalam perkembangan zaman,tidak dapat ditahan laju perkembangan situasi dan kondisi yang muncul. Oleh karena itu, perlu dilakukan penelitian ulang tentang beberapa pendapat hasil ijtihad ulama terdahulu, agar hasil ijtihad itu selalu sesuai dengan situasi dan kondisinya. Jadi yang mereka ijtihadkan bukan hanya masalahmasalah yang belum ada hukumnya, tetapi juga mengadakan reinterpretasi

${ }^{169}$ Muhammad Abduh, Risalah Tauhid, hal. 26. 
terhadap hasil ijtihad terdahulu. ${ }^{170}$

Bagi kelompok kedua yang awam, sikap yang harus diambilnya adalah mengikuti pendapat orang yang mereka percayai, dengan mempertimbangkan kedalaman ilmu dan ketaqwaan dari orang yang diikutiya pendapatnya. Jadi setiap dikerjakan oleh orang awam mempunyai dasar kuat yang dia sendiri mengetahui dasarnya dan tidak mengamalkan suatu perbuatan secara pembabi buta. Dengan sikap ini, umat Islam akan selamat dari bahayatak lid. Abduh berpendapat bahwa kebenaran dapat didapatkan dimana-mana, tidak hanya pada seorang guru atau suatumadzhab tertentu.

Menurut Rasyid Ridla, madzhab dalam pengertian Muhammad Abduh adalah lebih ditekankan pada cara pengambilan hukum dari nash yang ditempuh oleh seorang mujtahid tertentu. Jadi bukan dalam artian mengikuti dan tunduk pada hasil mujtahid tertentu, tetapi bermadzhab adalah dengan mengikuti cara-cara atau metode yang mereka tempuh dalam beristinbath hukum. Dengan demikian bermadzhab bukan bagi mereka yang awam, seperti umum dipahami, tetapi bagi mereka yang berijtihad dalam lingkungan madzhab tertentu. Mereka ini dalam istilah Ushul Fiqh adalah Mujtahid Bi al-Madzhab. ${ }^{171}$

\footnotetext{
${ }^{170}$ Muhammad Abduh, Risalah Tauhid, hal. 29.

${ }^{171}$ Sayyid Qutub, Khasha'ish At-Tashawwur AlIslam, hal. 79.
}

Maka fanatisme madzhab yang biasanya terjadi di kalangan awam dapat dihindari dan sikap taklid bisa diatasi. Akan tetapi, menurut Abduh, yang terjadi di masyarakat adalah sebaliknya. Generasi sesudah mujtahid mengikuti hasil ijtihad yang mereka dapatkan, bukan mengambil cara yang ditempuh oleh para imam. Akibatnya, terjadinya perselisihan pendapat yang membawa perpecahan di kalangan muslimin sendiri. Fanatisme madzhab pun mucul dan taklid tidak bias dihindarkan.

Abduh menuding para fuqaha sesudah mujtahid sebagai peletak batu pertama dari timbulnya fanatisme tersebut, dengan menambah atau memperluas hasil ijtihad para ulama terdahulu. Sehingga menurutnya ajaran agama dengan segala permasalahannya bukan semakin jelas, namun semakin rumit. Orang tidak bisa membedakan antara ajaran dasar Islam dengan ajaran madzhab yang bersumber dari fuqaha. Kitab madzhab dijadikan bahan rujukan dan kitab al Qur'an ditinggalkan, sehingga seakan-akan sia-sia Allah mengutus Rasul yang membawa kitab tersebut. 172

Oleh karena itu, dalam berijtihad kaum muslimin harus berpedoman kepada al Qur'an dan as Sunnah. Hal inilah yang mendorongnya untuk menggalakkan ijtihad di kalangan intelektual dan mengikis taklid

${ }^{172}$ Muhammad Abduh, Risalah Tauhid,, hal. 40.

186 | Hukum Menghadirkan Saksi Pada Transaksi Utang Piutang Perspektif Muhammad Abduh 
buta dalam masyarakat. Beliau membandingkan sikap umat Islam yang demikian itu dengan sikap kaum Yahudi yang taklid kepada pendapat pemimpin agama mereka, seperti digambarkan Allah dalam surat at-Taubah, ayat 32 . Sehingga mereka mengalami kemunduran setelah memperoleh kejayaan.

Tantangannya yang keras terhadap taklid tampaknya juga dilandasi oleh pandangan teologinya yang memberikan harkat yang tinggi kepada manusia dengan anugerah akal yang ada padanya, di samping kebebasan untuk mempergunkan akal tersebut. Dengan keduanya, seharusnya manusia juga mampu memahami nash-nash yang mujmal. Dengan demikian manusia tidak selayaknya tunduk dan mengikuti hasil pemikiran orang lain tanpa memikirkan alasan-alasan yang mendasari pendapat tersebut. Walaupun beliau juga mengakui bahwa tidak semua orang sanggup berijtihad. Akan tetapi bagi mereka yang awan pun taklid tidak boleh dilakukan.

Di samping itu, agaknya apa yang dia saksikan di Barat juga merupakan salah satu sebab tantangannya yang keras terhadap taklid. Dia melihat kemajuan barat yang menurut pemahamnnya disebabkan oleh terbebasnya mereka dari ikatantakl id dan bebasnya mereka dalam menggunakan akal dalam berpikir dan memahami sesuatu. Tampaknya Abduh menginginkan keadaan seperti itu bias diterapkan di kalangan muslimin, sehingga kemajuan di Barat dapat juga dirasakan kaum muslimin dengan lebih baik.

2. Akidah

Sebagai seorang pemikir yang termasuk mengagungkan akal sebagai sumber inspirasi kehidupan, Abduh sedikit banyak dipengaruhi pemikiran-pemikiran mu'tazilah. Hal ini terlihat dari buku-bukunya, di antaranya Risâlah Tauhîd. Pemikiran Abduh mengenai qada dan qadar, agaknya sejalan dengan sikap dan pandangan hidupnya yang dinamis. Di samping memandang qada dan qadar sebagai salah satu segi aqidah Islamiyah yang penting, ia juga menekankan pentingnya pemahaman yang benar dalam masalah ini. Meskipun tampaknya dia tidak menyebut soal qada dan qadar sebagai salah satu pilar-pilar keimanan, tetapi dia memasukkan masalah ini ke dalam aspek aqidah Islamiyah. Rupanya pendapat Abduh ini tidak jauh berbeda, untuk tidak dikatakan sama, dari pendapat gurunya, Jamaluddin al Afghany dalam masalah ini. ${ }^{173}$

Menurutnya, bahwa keyakinan yang benar tentang masalah qada' dan qadar akan membawa muslimin ke arah kejayaan dan kemajuan. Sebaliknya pemahaman yang salah terhadap keduanya, akan menyebabkan mereka ke dalam kehancuran. Seperti yang pernah

${ }^{173}$ Muhammad Abduh, Risalah Tauhid, hal. 42. 
terlihat dalam sejarah Islam.

Pemahaman Abduh tentang hal ini, mungkin disebabkan kondisi yang dilihat olehnya, baik dalam pengembaraannya ke negeri-negeri Barat, maupun kondisi Mesir sendiri yang masih dalam jajahan Perancis. Dia melihat aqidah yang dianut umumnya umat Islam ketika itu, yaitu paham qada' dan qadar yang telah berwujud fatalisme, yang justru telah membuat mereka dalam keadaan statis dan beku. Konsekuensinya, umat semakin mundur dan tidak ada kemauan untuk berbuat yang lebih baik.

Konsekuensi logis dari pendapat ini adalah manusia bebas menjatuhkan pilihannya. Dan apapun perbuatan yang dipilih dan dilakukannya, Tuhan telah lebih mengetahuinya. Jadi, peran Tuhan dalam hal ini adalah mengetahui, dan peran tersebut tidak menjadi penghalang bagi kebebasan manusia dalam memilih perbuatan sesuai dengan kehendak bebasnya yang diberikan Tuhan.

Mempercayai qada' dan qadar, menurutnya adalah juga meyakini bahwa setiap kejadian atau peristiwa dilatar belakangi oleh sebab. Rangkaian sebab-sebab tersebut menciptakan suatu keteraturan. Sehingga kejadian atau peristiwa yang telah berlalu dapat ditelusuri atau dipelajari. Sumber dari segala sebab tersebut, menurut Abduh, Allah adalah Tuhan yang mengatur segala sesuatu menurut kebijaksanaanNya. Dia menjadikan setiap peristiwa menurut hukumnya sendiri yang merupakan komponen dari suatu kerangka atau sistim yang tidak berubah-ubah. Itulah yang disebutnya dengan istilah sunnatullah (hukum alam Tuhan), dan manusia tidak dapat melepaskan diri serta harus tunduk kepada setiap sunnah yang ditetapkan Tuhan. Maka, keyakinan yang kuat terhadap hukum alam bukanlah berarti mengingkari adanya kekuasaan Tuhan, justru hal itu sejalan dengan keyakinan akan kekuasaan-Nya yang telah menciptakan hukum alam tersebut. Dengan demikian, nasib manusia akan sesuai dengan apa yang telah dipilihnya. Pandangan Abduh yang demikian akan lebih jelas terlihat ketika dia membicarakan masalah perbuatan manusia. ${ }^{174}$

Menurutnya, manusia adalah makhluk yang memiliki kebebasan dalam memilih dan menentukan perbuatannya. Manusia dengan akalnya mempertimbangkan akibat perbuatan yang akan dilakukan, kemudian dia mengambil keputusan dengan kemauannya sendiri dan selanjutnya mewujudkan perbuatan itu dengan daya yang ada pada dirinya. Jelas bahwa bagi Muhammad Abduh, manusia secara alami mempunyai kebebasandalam menentukan kemauan dan perbuatan. Manusia tidak berbuat sesuatu kecuali setelah dia mempertimbangkan akibat-akibatnya dan atas

${ }^{174}$ Muhammad Abduh, Risalah Tauhid, hal. 50.

188 | Hukum Menghadirkan Saksi Pada Transaksi Utang Piutang Perspektif Muhammad Abduh 


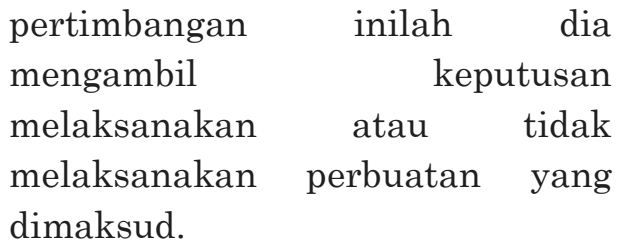

Namun, manusia tidak mempunyai kebebasan tanpa batas atau kebebasan absolut. Abduh membatasi kebebasan manusia dengan memberikan contoh yang tergambar dalam peristiwaperistiwa alamiah, seperti angin badai, kebakaran dan peristiwaperistiwa lain yang tak terduga. Artinya, kebebasan manusia mempunyai batas-batasnya, terutama sekali karena di atas manusia masih ada kekuasaan Tuhan. Kekuasaan Tuhan yang membatasi kemauan dan kebebasan manusia itu terjadi melalui hukum ciptaan Tuhan. Tuhan menjadikan segala wujud di alam ini di bawah hukum alam, dalam suatu sistem hukum sebab akibat yang ditetapkan-Nya. Atas dasar itu, kiranya dapat dikatakan bahwa terjadinya peristiwaperistiwa yang mengakibatkan kerugian pada manusia sebenarnya disebabkan oleh ketidak mampuan manusia sendiri dalam menguasai dan mengantisipasi hukum alam yang berintikan hukum sebab akibat itu. ${ }^{175}$ Menghadirkan saksi pada transaksi hutang piutang Islam memotivasi agar transaksi utang yang dilakukan di tengah masyarakat dicatat. Allah berfirman,

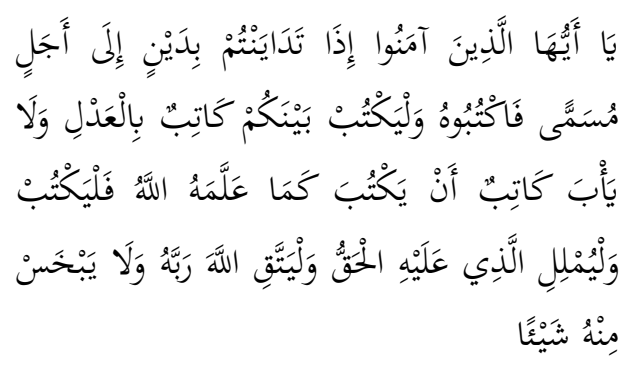

Hai orang-orang yang beriman, apabila kamu bermu'amalah tidak secara tunai untuk waktu yang ditentukan, hendaklah kamu menuliskannya. dan Hendaklah seorang penulis di antara kamu menuliskannya dengan benar. dan janganlah penulis enggan menuliskannya sebagaimana Allah mengajarkannya, maka hendaklah ia menulis, dan hendaklah orang yang berhutang itu mendektekan (apa yang akan ditulis itu), dan hendaklah ia bertakwa kepada Allah Tuhannya, dan janganlah ia mengurangi sedikitpun dari hutangnya.(QS. al-Baqarah: 282).

Secara tekstual, ayat ini di atas berisi perintah untuk menulis utang yang dilakukan manusia. Hanya saja ulama berbeda pendapat dalam memahami perintah ini, apakah menunjukkan wajib, ataukah hanya anjuran.

Pertama, madzhab dzahiriyah, ayat ini menjadi dalil wajibnya menulis transaksi utang piutang yang pelunasannya tertunda. Ibnu Hazm adz-Dzahiri mengatakan,

$$
\begin{aligned}
& \text { فإن كان القرض إلى أجل، ففرض عليهما أن } \\
& \text { يكتباه وأن يشهدا عليه عدلين فصاعدا أو رجلا إنا }
\end{aligned}
$$

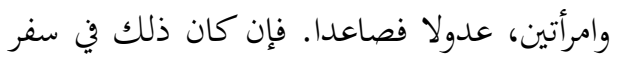

$$
\begin{aligned}
& \text { ولم يجدا كاتبا فإن شاء الذي له الدين أن يرتن به وله } \\
& \text { رهنا فله ذلك }
\end{aligned}
$$

${ }^{175}$ Muhammad Abduh, Risalah Tauhid,, hal. 51. 
Jika utang ditangguhkan pelunasannya, maka wajib bagi keduanya untuk menuliskannya dan mencari saksi dua orang atau lebih atau seorang lelaki dengan dua wanita yang adil, atau lebih. Jika dia dalam safar, dan tidak menemukan orang yang mencatat, jika mau, orang yang berutang bisa menggadaikan sesuatu. ${ }^{176}$

Kedua, mayoritas ulama dari kalangan hanafiyah, malikiyah, syafiiyah, dan hambali, berpendapat bahwa mencatat transaksi utang menghadirkan saksi ketika transaksi, hukumnya tidak wajib. Sementara perintah dalam ayat sifatnya bimbingan agar manusia lebih hati-hati dan lebih yakin dalam melakukan muamalah dengan orang lain, terutama masalah utang. Sehingga statusnya bukan perintah yang wajib dikerjakan.

Imam as-Syafii menjelaskan dengan bagus tafsir ayat ini. Beliau menyebutkan, ada dua alasan, mengapa perintah dalam ayat di atas (al-Baqarah: 282) bukan perintah wajib,

1. Di ayat berikutnya (283), Allah perintahkan ketika seseorang tidak menemukan penulis, agar menggadaikan barangnya.

2. Di lanjutan ayat, Allah bolehkan untuk tidak menggadaikan barang, selama masing-masing yakin bisa saling menjaga amanah.

As-Syafii dalam Ahkam alQuran mengatakan,

176 Ibnu Hadzm adz- Dzahiri, Al Muhalla bil atsar, (Beirut: Dar- alfikr) jilid 6, hal. 353.

$$
\begin{aligned}
& \text { فلما أمر إذا لم يجدوا كاتبا بالرهن، ثم أباح ترك }
\end{aligned}
$$

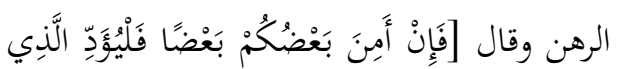

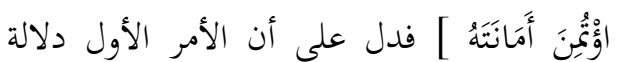

$$
\begin{aligned}
& \text { على الحظ لا فرض فيه يعصي من تركه. }
\end{aligned}
$$
untuk menggadaikan barang, apabila tidak menemukan penulis, kemudian Allah bolehkan untuk tidak menggadaikan barang, melalui firman-Nya,

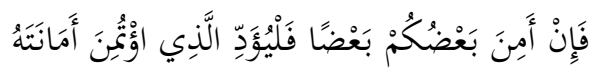

Jika kamu dalam perjalanan (dan bermu'amalah tidak secara tunai) sedang kamu tidak memperoleh seorang penulis, Maka hendaklah ada barang tanggungan yang dipegang[180] (oleh yang berpiutang). akan tetapi jika sebagian kamu mempercayai sebagian yang lain, Maka hendaklah yang dipercayai itu menunaikan amanatnya (hutangnya) (QS. al-Baqarah: 283)

Ini menunjukkan bahwa perintah di ayat sebelumnya, memberi kesimpulan anjuran, dan bukan kewajiban yang ketika ditinggalkan, bernilai maksiat. ${ }^{177}$ (Ahkam al-Quran, 2/127).

Sementara itu, Imam Abu Bakr al-Jasshas - ulama hanafiyah - (w. $370 \mathrm{H}$ ) menjelaskan bahwa para ulama sepakat, adanya catatan dan kehadian saksi dalam transaksi utang piutang, hukumnya tidak wajib. Dibuktikan dengan banyaknya transaksi utang piutang sejak masa silam, dan

\footnotetext{
177 Abu bakar ar radzi al Jashas, Ahkamul quran, (Beirut:Dar ihya' turats al arabi) jilid 2, hal. 127.
}

190 | Hukum Menghadirkan Saksi Pada Transaksi Utang Piutang Perspektif Muhammad Abduh 
turun temurun hingga masa

beliau, namun mereka tidak mencatatnya dan tidak menghadirkan saksi.

Dalam karyanya Ahkam alQuran, Beliau mengatakan.,

$$
\begin{aligned}
& \text { ولا خلاف بين فقهاء الأمصار أن الأمر بالكتابة } \\
& \text { والإشهاد والرهن المذكور جميعه في هذه الآية ندب } \\
& \text { وإرشاد إلى ما لنا فيه الحظ والصلاح والاحتياط } \\
& \text { للدين والدنيا، وأن شيئاً من ذلك غير واجب. }
\end{aligned}
$$

Tidak ada perselisihan diantara ulama dari berbagai negeri, bahwa perintah untuk menulis dan mengambil saksi, serta menggadaikan barang, seperti yang disebutkan dalam ayat, statusnya anjuran dan bimbingan, yang lebih memberikan keuntungan dan kebaikan bagi kita, serta kehati-hatian dalam masalah utang dan urusan dunia. Dan semua itu tidak wajib.

Kemudian

beliau melanjutkan,

$$
\begin{aligned}
& \text { وقد نقلت الأمة خلفا عن سلف عقود المداينات } \\
& \text { والأشربة والبياعات في أمصارهم من غير إشهاد، } \\
& \text { مع علم فقهائهم بذلك من غير نكير منهم } \\
& \text { عليهم، ولو كان الإشهاد واجبا لما تركوا النكير } \\
& \text { على تاركه مع علمهم به. وفي ذلك دليل على } \\
& \text { أفم رأوه ندبا، وذلك منقول من عصر النبي صلى } \\
& \text { الله عليه وسلم إلى يومنا هذا }
\end{aligned}
$$

Umat generasi sekarang telah mengikuti pendahulunya dalam akad utang-piutang, jual beli di berbagai daerah, tanpa adanya saksi. Padahal para ulama mereka mengatahui, tanpa ada pengingkaran ulama untuk mereka. Andai menghadirkan saksi itu wajib, tentu mereka tidak akan tinggal diam untuk mengikari orang yang tidak melakukannya, padahal mereka tahu. Ini menunjukkan bahwa mereka menganggap hal itu sifatnya anjuran. Dan semacam ini dinukil dari sejak masa Nabi shallallahu 'alaihi wa sallam sampai masa kita saat ini. ${ }^{178}$

Dengan memperhatikan keterangan di atas, menunjukkan bahwa hukum asal pencatatan dan saksi dalam transaksi utang itu sifatnya anjuran. Akan tetapi, jika bisa dipastikan akan menimbulkan sengketa dan pertikaian jika tidak ada pencatatan, maka mencatat transaksi utang atau menghadirkan saksi dalam hal ini statusnya wajib. Rincian semacam ini, disampaikan oleh Imam asSa'di dalam tafsirnya,

$$
\begin{aligned}
& \text { الأمر بكتابة جميع عقود المداينات إما وجوبا وإما } \\
& \text { استحبابا لشدة الحاجة إلى كتابتها، لأهما بدون } \\
& \text { الكتابة يدخلها من الغلط والنسيان والمنازعة } \\
& \text { والمشاجرة شر عظيم }
\end{aligned}
$$

Perintah untuk mencatat setiap akad utang piutang, bisa hukumnya wajib, dan bisa anjuran. Mengingat besarnya kebutuhan untuk mencatatnya. Karena jika tanpa dicatat, rentan kesalahan, lupa, peselisihan, dan pertikaian, yang itu kejelekan yang besar. ${ }^{179}$

Menghadirkan saksi pada

\footnotetext{
${ }^{178}$ Abu bakar ar radzi al Jashas, Ahkamul quran, (Beirut:Dar ihya' turats al arabi) jilid 1, hal. 482.

179 Syaikh Abdurrahman bin Nashir As Sa'di, Taisir al-Karim ar-Rahman Fi Tafsir Kalam alMannan, (Pustaka Sahifaal arabi), hal. 118.
} 
transaksi hutang piutang perspektif Muhammad Abduh

Muhammad

Abduh

berpandangan bahwa hukum

menghadirkan saksi pada

transaksi hutang piutang adalah wajib. Pendapat ini didasari firman Allah Swt pada surat al- Baqarah ayat 282 :

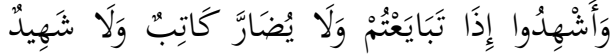

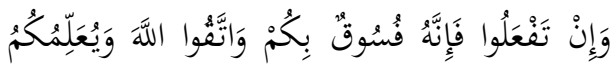

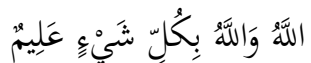

Artinya: Dan ambillah saksi apabila kamu berjual beli, dan janganlah menulis dipersulit dan begitu juga saksi. Jika kamu lakukan (yang demikian), maka sungguh, hal itu suatu kefasikan pada kamu. Dan bertakwalah kepada Allah, Allah memberikan pengajaran kepadamu, dan Allah maha mengetahui segala sesuatu.

Muhammad

Abduh menjelaskan bahwa sesungguhnya faidah kesaksian terhadap suatu transaksi yang bertempo, yang mana kebiasaannya pembayaran hutang akan ditangguhkan dalam masa waktu tertentu maka akan diselipi lupa. Maka dalam kasus ini, kesaksian pada transaksi utang piuatang tersebut merupakan sarana untuk menjaga harta manusia. Hal itu dikarenakan, kedua belah pihak akan menyadari hak dan kewajiban mereka masing- masing. Dengan adanya kesaksian terhadap utang, pemberi hutang tidak akan menambah- nambah jumlah hutang, dan tidak pula menagih hutang sebelum jatuh temponya. Begitupula seseorang yang berhutang, dengan adanya kesaksian pada utang- piutang yang ia lakukan maka ia tidak akan menghindar, lari atau menolak membayar hutang pada waktu yang telah ditentukan. Dari iti tidak ada yang meragukan manfaat- manfaat diatas pada menghadirkan saksi dalam transaksi utang- piutang. Dari itu perintah pada firman Allah ditas adalah wajib. ${ }^{180}$

\section{PENUTUP}

Muhammad Abduh merupakan sosok pemikir yang mencoba menyeimbangkan nash dan akal. Menurtnya keterlibatan akal dalam setiap aspek ajaran agama sangat dibutuhkan. Dalam membangun pemahaman Islam yang baik, umat Islam harus menggunakan akalnya, agar terhindar dari kesulitan dan mendapatkan manfaat (jalb al mashalih wa dar al mafasid). Hal ini terlihat pada pendapat beliau mengenai hukum menghadirkan saksi dalam trnsaksi utang piutang. Walau terkesan terktualis- literalis, namun pada prinsipnya abduh menitik beratkan mashlahah untuk mewajibkan tersebut. Menghadirkan saksi dalam trnsaksi utang piutang sangat berperan jika nantinya terjadi misunderstanding diantara kedua belah pihak.

Disisi lain Muhammad Abduh tidak mengikti Madzhab tertentu, dimana beliau tidak sependapat dengan Jumhur Ulama. Walau pada permasalahan lain beliau terkadang

180 Muhammad Imarah, al- A'mal kamilah lil syeikh Muhammad Abduh, (Cairo; Dar as- Syruq, tt) jilid, 1, hal. 247. 
sependapat dengan Jumhur dang madzhab- madzhab lain.

terkadang sependapat dengan 


\section{DAFTAR PUSTAKA}

Abu bakar ar radzi al Jashas, Ahkamul quran, (Beirut:Dar ihya' turats al arabi

Al-Tanahi. Ed., Muzakkirat Al-Imam Muhammad Abduh, Cairo, Dar AlHilal

H. Munawir Sjadzali, Islam dan Tata Negara Ajaran, Sejarah dan Pemikiran (Jakarta: Universitas Indonesia (UI Press), 1990)

Ibnu Hadzm adz- Dzahiri, Al Muhalla bil atsar, (Beirut: Dar- alfikr)

Muhammad Abduh, Risalah Tauhid, (Jakartan: Bulan Bintang, 1989), V. Diterjemahkan oleh K.H.Firdaus A.N

Muhammad Imarah, al- A'mal kamilah lil syeikh Muhammad Abduh, (Cairo; Dar asSyruq, tt)

M. Quraish Shihab, Studi Kritis Tafsir Al-manar (Bandung: Pustaka Hidayah, 1994)

Nur Cholis Madjid, Islam Kemodernan Dan Keindonesiaan, (Bandung: Mizan, 1989)

Sayyid Qutub, Khasha'ish At-Tashawwur Al-Islam

Sayyid Quthb, Kasha'ish Al-Tashawwur Al-Islamiy (tanpa tahun), cetakan III, 1968

Shihab, Studi Kritis, 12. Dikutip dari Sayyid Muhammad Rasyid Ridha, Tarikh AlUstadz Al-Imam Muhammad Abduh, Juz 1, Percetakan Al-Manar, Mesir

Toto Suharto, Filsafat Pendidikan Islam, (Yogyakarta: Arruzz, 2006 